Copyright (C 2015 by Academic Publishing House Researcher

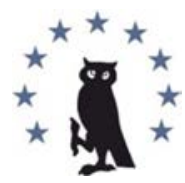

Published in the Russian Federation

European Researcher

Has been issued since 2010.

ISSN 2219-8229

E-ISSN 2224-0136

Vol. 96, Is. 7, pp. 470-479, 2015

DOI: $10.13187 / \mathrm{er} .2015 .96 .470$

www.erjournal.ru

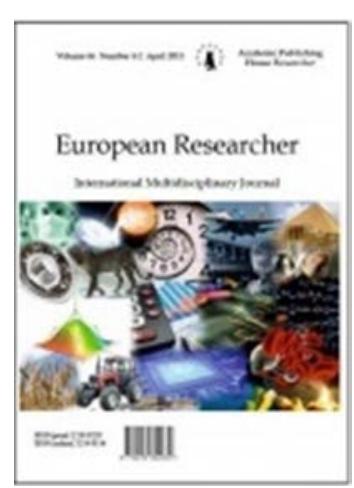

UDC 33

\title{
Exploitation of labour: A study of Migrant labourers in West Bengal
}

\author{
Sribas Goswami
}

Serampore College, West Bengal, India

$\mathrm{PhD}$, Assistant Professor, Department of Sociology

E-mail: sribasgoswami@gmail.com

\begin{abstract}
Migrant workers, who constitute a major work force, in the unorganized sector, face various psychological stresses and arrive in an aggravated mental position due to their habit of using different varieties of intoxicants. The researcher's attempt in this paper is to find out the connection of addiction- related stress and social disintegration of the migrant workers with the wide web of exploitation of labour through an empirical analysis. The intoxicants are the only medium for the migrants to leave the sufferings behind them for a time being. This paper highlights the push factors as the fabricated trap to exploit the migrants physically, socially and mentally for surplus production with cheap labour.
\end{abstract}

Keywords: Health, labour, exploitation, employment, fundamental rights.

\section{Introduction}

Health is always considered as wealth. "Health is a state of complete physical, mental and social well being and not merely the absence of disease or infirmity: it is a fundamental human right and ... the attainment of the highest possible level of health is a worldwide social goal whose realization requires the action of many other socio- economic and political sectors in addition to the health sector."** All dimensions of socio- economic, political and cultural conditions such as food, water supply, education, housing, employment, reasonable wage and circumstances of creativity etc. play a vital role in maintaining health. The structural analysis shows different levels of life negations in the health issues of migrant labourers. Deprivations of land, means of production, surplus extraction by using technologies and extension of the time of the work, deprivation of wage and low wages etc. constitute through alienation to the labourer. Since labour is defined as 'any economically productive activity' and the major labour force of India is marginal workers. ${ }^{2}$ the welfare of a nation depends on the well being of this work force. If the labour force is weak, alienated from the production, then the outcome will be a weak economy. Thus it must be protected and secured from all types of illness, exploitation and alienation which prevent them from creating a better society. Patnaik argues that "those interested in the progress of this country

\footnotetext{
* Naresh Banerjee, "Health Diseases and Drugs." In Drug Industry and Indian People, edited by Amit Sen Gupta (Delhi: Delhi Science Forum and Federation of Medical Representations, 1986), 43, (Hereafter, Banerjee, Health Diseases and Drugs....).
} 
must present before the people an alternative agenda of the citizenship that transcends specific identities and ensures for every one the prerequisites for a meaningful life." 3 Thus Affirmation of Life' in labour denotes a healthy contented labour force of a community. This chapter focuses on different approaches and alternatives to have a life affirming labour.

\section{Methodology:}

For an accurate understanding of the existing interconnectedness of labour and addicted related health issues, an empirical study was conducted in the five labour crowded areas of Kolkata, West Bengal, India. A questionnaire was prepared and was personally handed over to and answered by the Bihari migrant workers of that area. The Hindi version of the English questionnaire was disturbed. 108 samples were taken along with a few interviews with workers, religious leaders and representatives of the Government.

\section{Counseling}

Counseling method helps if there a dilemma of loneliness and alienation. Migrant labourers are disconnected from their community and social support. They need some confidence within themselves to accept the reality around them and the ability to face the challenges. They must develop a powerful mind to say 'no' to certain things that may harm them permanently. Adapting a healthy life style, exercising, breathing techniques, yoga, increasing will power and controlling cravings are the best way to quit addiction. * Stanley's study on material dynamics in alcoholism discovered that poor marital adjustment and higher conflict levels were seen in families complicated by alcoholic consumption. ${ }^{5}$ Thus to have a healthy personal and family life, the guidance of professional counselors is a vital need amongst migrant workers.

P.Sudhagar suggests starting tobacco cessation centers and 'quit lines', 6 with counseling and nicotine replacement therapy to help people come out of addictions. There are de-addiction centers to give recovery to the addicted persons, particularly at least three of them in $15 \mathrm{~km}$ radius of Kolkata, but the cost of counseling treatment is somewhat high to the poor workers. Here the support of charity organization, NGOs and other religious organizations are required.

\section{Conscientization}

Awareness and conscientization are the basics, when we dream of a healthy labour community. Many of the migrant labourers having very little knowledge about the present world scenario. The main concern for them is 'survival'. From such a community we can expect nothing other than their primary enjoyment, for which they won't think how it adversely affects their health. Together with tobacco and alcohol. Physical inactivity and unhealthy diets are the common risk factors associated.7 Smokeless tobacco comes in various forms like gutka, zarda, mishri, mawa and pan masala and is cold cheaply in small outlets. ${ }^{8}$ Smokeless tobacco causes a burning sensation in the mouth, a wet leathery feeling, and reduced mouth opening... it can lead to bleeding gums ${ }^{9}$ and may finally lead to cancer. So a thorough awareness is compulsory to the migrant workers regarding the pros and cons of addictive substances.

Along with knowing the health issues, they should know their rights and duties and more particularly should have a "Third Eye" 10 to sense the area of exploitation in day to day life affair.

\footnotetext{
2 “Smoke going down”, Down to Earth 7/19 (February 28, 1999): 25.

${ }^{3}$ John Philip, "Marital Adjustment Among the Wives of the Alcoholics in relation to Codependency and Selected Socio Demographic Variables," TAMIC Journal of Counselling 1/1 (June 2014): (Hereafter, Philip, Marital Adjustment....).

${ }^{4}$ P.Sudhagar, "Anti- Tobacco Campaign to be Launched," The Hindu, 29 April 2009, 5. (Hereafter, Sudhagar, Antitobacco ....).

${ }^{5}$ Aarti Dhar, "Frame Work Convention on Alcohol Control Mooted," The Hindu, 30July 2008, 5. (Hereafter, Dhar, Frame Work....).

${ }^{6}$ R.N. Karla, "Snuff out the cigarette, not life," The Hindu, 3 June 2012, 12. (Hereafter, Karla, Snuff out...).

${ }^{7}$ Sneha Nalawade, "Wiser man, not a tobacco fan," The Hindu, 3 June 2012, 12. (Hereafter, Nalawade, Wiser man ...).

8 C.S. Song, Third- Eye Theology: Theology in Formation in Asian settings (London: Lutterworth press, 1980), xi. (Hereafter, Song, Third-Eye Theology....).
} 
Thus Gabrielle Dietrich says that the "labourers should understand themselves in a better way."11 Education should be given to the workers to prepare them for participative management,"12 The labourer should know their obligations to the family and the country first and should be taught broadly about the economy of the country..$^{13}$ As Paulo Freire suggests, conscientization through the action reflection model or dialectical learning ${ }^{14}$ is significant, when we educate the labourers.

\section{Care}

Addictive drug subsistence affects primarily the mental capacity of a person. As psychologists understand it, it will affect the cognitive process of a person such as perception and attention, and finally destroys working memory. ${ }^{15}$ Abnormal usage of alcohol and chewable drugs will result in behavioural sedation and will impair social or occupational functioning even slurred speech. ${ }^{16}$ Alcohol affects many parts of the body including stomach, small intestine, blood vessels and heart, and some substances will go to the lungs. This leads to lack of concentration and reduced appetite. Long term usage of this will of course end up in anxiety, agitation and most extreme withdrawal. Tobacco related chewing also drives one to depression, anxiety, restlessness, decrease of appetite and weight loss. ${ }^{17}$

In such scenario, the patients need immediate medical help not to get relief from 'thick' ${ }^{18}$ but to get out of all related physical weakness. Unfortunately in Kolkata, there is only one primary health center with a very minimum facility. To a large extent migrants depend upon private medical practitioners and private hospitals, where the payment will be very high. The migrant workers should not be considered as second hand citizens but should be treated as essential citizens to be taken care of.

\section{Fundamentalistic Approach of the State}

The fundamentalist approach of the state unveils procapitalistic neoliberal economic policies of the Government and shows how it would be a threat to the affirmation of life.

\section{Agrarian Economy}

The new economic policies of successive central governments since the 1990s became more pro industrial and were against the local agrarian economy. Professionalism and hard work become the only way for the working class to lead a meaningful life. ${ }^{19}$ "Neo-liberal economic policies mandate low or no investment in agriculture and rural infrastructure." 20 The non- remunerative agriculture, low productivity, absence of adequate procurement of surplus harvests etc. became the main reasons for large scale migration. ${ }^{21}$ Now the so called 'Manmohanomies'22 has been taken up a draconic shape into "Namonomics"23 of the Indian economic dealings, where little importance is given to local and rural economies.

\section{Rapid Urbanization}

Prof. Sudhir Kumar, a social activist, warns us that the ever alarming increase of urbanization is the main reason of migration. ${ }^{24}$ Consequently, Sudhir finds, it has linkage to the stagnation of agriculture and the agrarian economy. Scholar like Davis argues that third world urbanization is marked not only by its extremely rapid pace, but it is typically propelled by distress migration from collapsed agrarian economies. In other words, third world cities, desire rising unemployment, falling real wages, soaring prices, overcrowding and poor infrastructure, continue to attract an ever increasing number of rural migrants. ${ }^{25}$ So a collective rethinking is necessary to counter the existing economic policies and to form an alternative step which does not threaten the livelihood of the common people.

\section{Landlessness}

India has the largest number of rural poor as well as landless households in the world. 26 The landlessness of the Bengali people in the Malda region of North Bengal has to be revisited to know why many of them are landless. An interview with one among them reveals that they actually do not know about such details because for generations they have been undergoing the same situations. May be it is due to the uneven distribution of land or because of the dependency of big tenants in the area. ${ }^{27}$ If this issue were positively addressed by the Government and initiatives 
taken to distribute common lands for them, then people could have means to produce something for themselves. This demonstrates that the new land reform is need of the hour.

\section{Lack of Employment Opportunities}

It is important to note that unemployment and uneven development are products of the normal functioning of the capitalist system. ${ }^{28}$ Big corporations and MNCs will bring with them plants and equipment, denying opportunities of human power. "Goods produced by MNCs by virtue of the superior technology, attractive packaging and wide-spread and aggressive advertising are likely to result in a closure of local units." 29 This will directly affect the local initiatives of traditional livelihood. Unemployment opportunities are a must for the welfare of the people so that we can utilize the labour in a more productive way, not in the sense of export oriented but for equal sharing within the country.

\section{Working Conditions}

\section{Hours of Work and Protection}

By and large, the work in the construction field has involved heavy risk which is a serious threat to the workers. Long hours of work, low wages and minimum levels of coverage are reported everywhere. The demand for eight hours working remains an exploitative area still today. The working shifts. ${ }^{30}$ To meet the target of production the workers are not even allowed toilets and tea breaks in day is constantly lengthened, so much so that it is not uncommon to hear workers doing 14 to 16 many work sites. Working in multi storied buildings and shopping malls may involve hard labour and risk. In the case of injury there are no first aid facilities, either from the government or from the contractors. Causalities are very common. Thus for a life affirming labour force, we need to ensure all efforts to prove health protection to the labourers. Working time should be strictly limited to 8 hours and the payment of the wage must be justifiable to their labour.

\section{Wage and Legal Bonds}

"The minimum wage, usually set governments at impossible low levels, remains a struggle to obtain as a right. Wages are cut for the smallest of 'infractions' and delays, leave is not given and statutory payment remains unpaid," 31 The structural analysis proved that the workers engage in work without having any legal agreement with the contractors or with any mediators regarding their wages, hours of work, provision of living accommodation. Frequently they have only oral agreements of recruitment. There is no doubt that the contractors are keeping their labourers in inhuman terrible conditions with no amnesties such as water, electricity or toilets. ${ }^{32}$ Wages for migrant labour are often paid on the basis of daily wage rates and piece rates. There is no standard wage rate system. ${ }^{33}$ Medical insurance coverage is a must for them. The labourers must receive the basic dignity of human life. They should be provided with good accommodation, power supply, latrine facilities and drinkable water facilities, since the researcher had first hand witness of

\footnotetext{
27 Isha Maulavi, Interview .....2 June, 2014.

${ }^{28}$ Kumar, A Class Analysis....124.

${ }^{29}$ Gupte, Unemployment...., 4.

30 "Dead Labour, Living Labour," Economic and Political Weekly XL VIII/19 (May 11, 2013): 8. (Hereafter, Dead Labour...).

31 Dead Labour ...., 8.

32 Bhaskar Ghose, “Workers as Slaves," Frontline 27/7 (March 27-April 9, 2010): 118. (Hereafter, Ghose, Workers as Slaves...).

33 Pandey, Seasonal Migrant....414.

${ }^{34}$ Madhu Bharti, "Impact of Poor Urban Services on Health and Asset Creation- A Case Study Ahmadabad, "Social Action 56/2 (January, 2006): 159. (Hereafter, Bharti, Impact of Poor....).

35 Gabrielle Dietrich, "Poor against WTO," The Movement of India 1/3 (November- December, 2005 ): 14. (Hereafter, Dietrich, Poor against...).

36 “18 December 2007, International Migrant's Day," Labour File 5/5\&6 (September- December, 2007$): 84$. (Hereafter International Migrant's Day...)
} 
the contamination of drinking water and "the continuous presence of adour in many of their settlements. ${ }^{34}$

\section{Political Implementations}

The Government should reserve its stand on neoliberalism. Dietrich said that "the basic reorientation of economy is an imperative. Self reliance, land for the landless and poor, employment guarantee for all, enforceable right to food, water, housing, maternity benefits for women workers, free compulsory education, health services are our demands. India should be free from enslaving agreements with WB, IMF, and WTO." 35 So this shows the role of political initiative to have a life affirming labour.

The Government must ensure that migrants have access to justice and support services. The migrants accused of committing crimes need to have access to interpreters or legal aid. Migrants, who are suffering abuse, should have access to shelter, legal aid, medical care and temporary residence status. The Government should ensure speedy and transparent system to resolve wage disputes, and they must trial cases against migrants through the criminal justice system. ${ }^{36}$ The Government should trace all migrants, who are trafficked in domestic work, or who labour in factories and at construction sites and should show justice to them.

\section{International Measures}

The Declaration of Philadelphia (1944) annexed to the International Labour Organization's (ILO) constitution declares that "all human beings have the right to pursue their material wellbeing and their spiritual development in conditions of freedom and dignity, of economic security and equal opportunities." 37 That all human beings are born equal in dignity and before the law is the essence of the Universal Declaration of Human Rights (UDHR). It also states that "everyone has the right to a standard of living adequate for the health and well being of himself and his family, including food, clothing, housing, medical care and necessary social services, and the right to security in the event of unemployment, sickness, disability, widowhood, old age or other lack of livelihood in circumstances beyond his/ her control."38 The Human Development Report (HRD) made an assertion that the "ableness to decide where to live is the key element of human freedom." 39 Thus internationally serious decisions and deliberations have been made to support migrant workers, but if these have not become a national responsibility, they will be only a futile noise.

\section{National Measures \\ Enactment of Laws}

There was a time in India when workers were completely at the mercy of employers with no laws to check exploitation. But today at the national level we have plenty of laws ${ }^{40}$ ensuring the security of the labourers. But none of these laws of the Government is concretely useful to migration of labourers. The 1979 Migrant Workmen Act is inadequate to the ground realities of migrant workers. The Act does not cover the agricultural field or the workers engaged in framing. The revised version of the Act came in 2008 as the 'Unorganized Worker's Social Security Act' (UWSSA), which gives benefit of the previous Acts passed by the Indian Government to unorganized workers. But the implementation of the Act is not yet done. In various states different welfare schemes have been introduced to help migrant workers. That is a good sign, but they have to be instituted in other parts of the nation. So the implementation of the existing laws and the enactment of new policies and laws to support migrant workers are necessary steps to be taken by the Government.

\footnotetext{
${ }^{37}$ D. Pulla Rao, "Status of Women in Informal Sectors in India," Vikas Vani Journal VIII/1 (January- March, 2014): 5. (Hereafter, Rao, Status of Woman....).

38 Hand Book on United Nations Basic Principles and Guidelines on Development- based Evictions and Displacements (New Delhi: Housing and Land Rights Network, 2011), 3. (Hereafter, Hand Book on United Nations....).

${ }^{39}$ Migrations and Human Development..., 5.
} 


\section{Addiction- Free Villages}

The Government should promote the concept of 'smoke-free and drug free villages' on national scale. Along with the prohibition of liquor or any other drug items, the need for a through conscientization of its adverse effects upon the health of the people specifically labourers, must be promoted.

\section{Linguistic help and Education}

Above all the Government should take initiatives to give education to those who have none and those who want to upgrade their qualifications. If linguistic problems are affecting the life of migrants, there should be made available translator assistance in hospitals and other public spaces so that their lives will be more participatory in society. At the same time if migrants take some risk to learn the local language where they work, it will enable them to interact with the place where they stay and can escape from many areas of exploitation.

\section{Health Monitoring}

Though the above mentioned government activities are appreciable, the authorities should chalk out master plans for the complete health protection of migrant communities. Since the addicted persons never take initiatives, there is a need for frequent visits of medical aid volunteers in the camps of migrant workers. Health awareness programmes, medical camps, free health services etc. can be a good help to them. The quality of care and the accessibility of the public sector have to be improved and at the same time should be monitored whether the private sector is exploitative or not. The over-use of diagnostics and the over-the- counter sale of drugs must be checked immediately. Financial help and death compensation if any at the work place and ensuring protection of the workers from injury and other ill treatment etc are significant initiatives that the migrants hope to have from the Government.

\section{The Approach of Civil and Political Organizations}

There is a need for collective effort to counter all powers which stand against human welfare. Civil society is a collection of individual and collective initiatives for the common public good. ${ }^{41}$ Since the root of the problems lies at the social level, we need the co-operation of a creative civil society and a strong political involvement in creating life affirming labour.

\section{Politicization of Migration}

Politicization of migration is the most aggressive form of dehumanization. In many areas it has become a source of communal tensions. In many places local people feel threatened from changing demographic patterns and declining job opportunities. Hate speeches always get some political mileage at election time. Politicization results in the death of several people, gives injuries to hundreds and triggers the displacement of thousands. There are incidents related to sectarian and communal issues along with the 'sons of the soil' argument. Unless the political leadership makes a conscious and forceful effort to get out of these trappings, the issue of migration will not be addressed objectively and effectively. Here everyone should know that the nation is for the people, and in it each individual has a role to play for his / her own sustenance as well as the growth of the entire nation.

\footnotetext{
40 The Indian Labour Union Act (1926) was passed to give legal status to the labour unions and to recognize their right to strike for collective interest. The Industrial Disputes Act (1947) forbids any dismissal unless the employer gives one month's notice or a month's salary to the workers. If the employer makes new appointments, the retrenched worker would have the first claim for job. The Factory Act (1948) was passed to regulate conditions of labour, mainly with safety, health and welfare facilities working hours and provision for annual leave with wages. The Minimum Wages Act (1948) considered low wage and forced labour as a national offence. The Social Security Act (2008) mainly aims to protect the workers of the unorganized sector from unfair bargaining and other exploitation.

41 Paramjit S. Judge, "An Ambiguous Actor: People in The Movement" Economic and Political Weekly XL VI/46 (November 12, 2011). 19. (Hereafter, Judge, An Ambiguous Actor...).
} 


\section{Social Security and Welfare Schemes}

Social security is another area which needs serious consideration in migrant workers' lives. Rajalakshmi says, "Apart from being paid less than regular employees on corporate pay rolls doing similar tasks, contract workers have no job security and no benefits like medical aid, gratuity, provident fund, educational funds, pension and health insurance and leave benefits." Language and lack of documents providing identity are serious issues which affect their ability to make use of many of the laws and labour welfare aids of the State and Central Government. Even though West Bengalis considered as the first State to establish a comprehensive welfare scheme for migrant workers, the efforts to enroll members have so far not been very successful. Only a few have come forward to register their names. Here the cooperation of the migrant workers is indeed necessary.

Successive Governments in West Bengal are very keen on making budgetary provisions for the betterment of migrants. Along with welfare funds, they have made plans for building permanent camps for them in the three big cities and for providing pensions to them. For the last couple of years the West Bengal Government has provided a goodwill kit, as a special gesture, which contains vegetables and provisions to celebrate several community festivals with the local people.

\section{Workers Union}

As far as migrant workers are concerned they face organized deficiency. Normally for the workers of the organized sector, there will be trade unions to assist, but for the migrants there is no such collective support to bring their issues up in the political forum. Actually workers themselves should take initiatives to establish unions to defend their rights and advance their interest at the work place and at the broader social-political level. Otherwise the present trade unions should get the freedom to extend their activities to the unorganized working group, particularly to migrant workers. By nature, a trade union movement should be on the side of the weak, marginalized and the sidelined, within its own country and all over the world. But sometimes even unions are also not free from power, political forces and the capital, which neutralize their aggressiveness. Lack of good leaders, lack of awareness about their own strength and language barriers make it impossible for migrant labourers, to have a political oneness to form as workers unions to fight for justice.

\section{Return to Traditional Activities}

In present growth made visible the gap between upper class and lower class and replaced traditional equipments with modern advanced technologies to increase production. As a result, millions of people have been evicted from their own sources of production and have made to be just labourers. The medium and small scale cottage productions owned by many have become absorbed by mega companies which have pushed people out without livelihood. The heavy decline in employment opportunities due to sporadic technological implementations has made worse the condition of rural youth. The urbanization boom provides more possibilities to an emerging middle class to enjoy the same status with the elite.

A recent study in Kolkata concludes that the emigration of workers from Bihar to other parts of the world made a rapid demographic transition in the State. The workers of Bihar demand high wages but reluctant to do hard physical works. This causes the replacement migration in a rapid scale. The West Bengal people's way of sustaining themselves with the remittance of their relatives from abroad made them lazier. They withdraw from local traditional economic activities. This tendency has to be changed. Each job should be dignified and equal importance should be given to agriculture too along with other work.

\section{Recession to Procession: Less Consumerism}

Consumerism has been termed as madness in the present generation and analyzing every human action, even labour, in the context of business and benefits. Consumerism gives an argue to become elite and paves the way to consider the workers as their objects to make provision for their betterment. Using the work force to the maximum without considering how it affects the worker's health is part of this mentality. Here the work force is alienated from the production of their labour. Many families do not want to send their children to a hard and tiresome job, but use the weaker sections as servants and slaves. So we need a recession from the consumerist attitude to need oriented society, where every human must be treated as equal and significant. 


\section{People's Movement and Resistance}

Social movements are understood as organized efforts working towards achieving a change. It is an ideology to identify what is wrong with the present and what needs to be done in the future. When essential services are being privatized and the State is withdrawing from its responsibility, neglecting the directive principles enshrined in the Constitution and in the process trampling the fundamental rights of citizens, the struggle of the people's movement is to assert the rights of the people to resources, land, water, forest and other facilities essential for life affirmation. As a responsible citizen, the migrant labourer should know about how important he/she is in the economic practice of the nation. Thus of course she/ he should be conscious enough to understand what are his/her rights and duties as a labourer. Religious or secular movements are needful factors in Kolkata for the migrant labourers' collective resistance. This collectivity will equip them to stand up for common justice, a corruption-free world and a healthy community.

\section{Pastoral Challenges}

Creating a communitarian relationship in the locality and inviting the entire community to engage in a wider ecumenical discourse and actions, irrespective of religion and class, are the primary pastoral challenge of the time.

\section{Representation}

The attitude towards migrant labour, indeed labour in general, has to be changed. The community often shows elitism in their educational qualifications and pride in their foreign currency from migrants abroad, but at the same time considers Bengali migrants as a cultural symbol of backwardness, dirtiness and trouble, outside their concept of development. Thus "migrants of all classes are constantly subject to discrimination and suffer local prejudice" Here the Bengali community should learn to make an ideological shift in their dealings and should show a communitarian approach to migrant labourers.

\section{Recognition}

Recognition is the most basic gesture that any worker seeks as the reward of sincere work. Firstly, to recognize the worker as a co-human; secondly to consider the worker as co-worker; these are relevant in forming a life affirming labour. Solidarity is therefore a guiding principle that can never be compromised when we deal with the labour force anywhere in the world. Solidarity is not about speeches and resolutions of the faith community; it is all about the actions we are prepared to take, the resources we commit and the sacrifices we make to support working people elsewhere. In the time of festivals and special occasions workers should be invited and honored by the local community.

\section{Ecumenical Actions}

The analysis clearly shows the absence of recreation and socialization among the migrant labourers. They go to work early in the morning and return home late in the evening. In between they have little time to cook, bathe and socialize. The health of the worker depends to a great extend upon the mental strength at the person, which is absolutely related to how much recreation that person has. So some kind of physical or mental recreational and entertainment programmes are a must for migrant workers to keep themselves strong and healthy. Efforts should be made to gain the confidence of all religious and other sections of people along with migrant labourers to develop common programmes for common growth in order to confront fundamentalism and communalism.

\section{Conclusion}

This paper has dealt with traditional, fundamental, and collective approaches to formulate certain proposals to shape a life affirming labour community. The alternative approaches invite a reversal form present economic policies to give more emphasize on agricultural and traditional life styles. A popular movement with the support of a strong civil society is the need of the hour to resist human rights violations in the area of labour. Since the workers expect communitarian respect and, recognition of the service they render, the challenge for the pastoral community is to prepare situations for a wider ecumenical approach. The state has a role to play to uplift its citizens, 
wherever they are being neglected. In the case of migrants from Malda, Bengal, there is no Government support as such for agricultural activities, and no water supply and electricity. In certain areas they place offices to register their names, but the agents or the migrants themselves are not interested in it. "Migrants everywhere are employed in difficult and low paid jobs on temporary basis. They cannot expect social security and protection from labour laws, though they toil for the progress of the society" is the attitude of the Government. At the same time there are certain State Governments that provide them with basic relief activities.

\section{References:}

1. Abraham, K.C. Closed Doors and The Risen Christ, Sermons and Reflections on Being a Christian, Bangalore, Asian Trading Corporation, 2007.

2. Aland, Barbara and Kurt Aland, eds. The Greek New Testament, Fourth Edition Dictionary, Edmonds: United Bible Study, 1998.

3. Aron, Raymond, Main Currents in Sociological Thought. England: Penguin Press, 1986.

4. Banerjee, Naresh. "Health, Diseases and Drugs." In Drug Industry and Indian People. Edited by Amit Sen Gupta, Delhi: Delhi Science Forum and Federation of Medical Representations, 1986.

5. Barlow, David H. and V.Mark Durano, Abnormal Psychology: An Integrative Approach New York; Wadsworth Publishing Company.

6. Bella, Robert N, ed Emile Durkheim on Morality and Society, Selected Writings. Chicago: The University of Chicago Press, 1973.

7. Brich, Bruce, C. et al A Theological Introduction to the Old Testament. Nashville; Abingclm Press, 1999.

8. Carter, Warmen Mathew and the Margins: A Socio Political and Religious Reading. New Delhi: Theological Publication in India, 2007.

9. Chandrlie, Neera State and Civil Society, Explorations in Political and Religious Reading. New Delhi: Sage Publications, 1995.

10. Conzeh: A Commentary on the First Epistle to the translined by James W. Leitch. Philadelphia: Fortress Press, 1981.

11. Dietrich, G and Whelenga Bastian, Towards Understanding Indian Society, Thiruvalla, Christava Sahithya Samithy, 2011.

12. Dietrich G : A New Thing on Earth. Delhi: ISPCK, 2001.

13. Duchrow: Alternative to Global Capitalism, Drawn from Biblical History, Demographical and Political Action. Netherlands, International Books, 1995.

14. Durham, J ulian," Word Biblical Commentary, vol. 3.Texas: World Book Publications.

15. Durkheim, Emile "The Division of Labour in Society," in Social Theory a Research enlisted by J onathan J oseph, Edinburgh: University Press, 2005.

16. Echegavya, Elegies: The Practice of J esus, New York: Orbis Books, 1980.

17. Fisher, William. F and Thomas Ponniah. Another World is Possible: Popular Alternatives as Globalization at the World Social Forum, London: Zed Books, 2003.

18. Fretheim, Terence, E. Exodus, Interpretations: A Bible Commentary for Teaching and Preaching. Louisville: J ohn Knox Press, 1973.

19. Freire, Paulo, The pedagogy of the Oppressed. Translated by Myra Bergman Ramos. New York: Continuum Publishing Corporation, 1952.

20. George, Oommen, "The Eucharistic Identity of Christian Community," in In Search of Christian Identity in Global Community, Edited by M.J. J oseph, Thiruvalla, Christava Sahithya Samithy, 2009.

21. Gottwald, Norman, K. The Tribes of Yahweh, s Sociology of the Religion of the Liberated Israel 1250-1050 B.C.E. London: SCM Press, 1979.

22. Goswami, Sribas. Urbanization, Development and Discourse of slums, Renu Publishers, New Delhi, 1st Edition, 2015.

23. Goswami, Sribas. Public Sector Unit: The Tacit Dimensions published in European Journal of Social and Human Science, Slovakia, Vol.(3), № 3, 2014, pp. 118-124.

24. Hamilton, Victor. P. The Book of Genesis Chapters 18-50, The New International Commentary on The Old Testament. Michigan: William B. Erdmans Publishing Company, 1995. 
25. Hunsinger, George, ed, Karl Barth and Radical Politics. Philadelphia, Westminster Press, 1976.

26. Hunter, Rodney J., ed. Dictionary of Pastoral Care and Counselling. Nashville: Abington Press, 1990.

27. J ain, D.R. World's Great Economists. J aipur: Sublime Publications, 2009. 2005.

28. J oseph, J onathan, ed. Social Theory a Reader. Edinburgh: Edinburgh University Press,

29. Kaiser, Walter, C. Jr. "Exodus in The Expositor's Bible Commentary with the New International Version of the Holy Bible in twelve volumes (Vol.2). Edited by Frank E. Gaebelein. Michigan: Zondervan Publishing House, 1940.

30. Kappen, S. Divine Challenge and Human Response. Thiruvalla, Christava Sahitya Samithy, 2001.

31. Kappen, S. The Future of Socialism and socialism of the future. Bangalore, Vistar, 1992.

32. Klein, Naomi. The Shock Doctrine, The Rise of Disaster Capitalism. London: Penguin Books, 2007. 1992.

33. Kurien, C.T. The Economy an Interpretive Introduction. New Delhi: Sage Publications, 